University of Nebraska - Lincoln

DigitalCommons@University of Nebraska - Lincoln

Papers in Plant Pathology

Plant Pathology Department

1977

\title{
Alfalfa Latent Virus, a Naturally Occurring Carlavirus in Alfalfa
}

Yenkateswarlu Veerisetty

University of Nebraska-Lincoln

Myron K. Brakke

University of Nebraska-Lincoln

Follow this and additional works at: https://digitalcommons.unl.edu/plantpathpapers

Part of the Plant Pathology Commons

Veerisetty, Yenkateswarlu and Brakke, Myron K., "Alfalfa Latent Virus, a Naturally Occurring Carlavirus in Alfalfa" (1977). Papers in Plant Pathology. 173.

https://digitalcommons.unl.edu/plantpathpapers/173

This Article is brought to you for free and open access by the Plant Pathology Department at DigitalCommons@University of Nebraska - Lincoln. It has been accepted for inclusion in Papers in Plant Pathology by an authorized administrator of DigitalCommons@University of Nebraska - Lincoln. 
Etiology

\title{
Alfalfa Latent Virus, a Naturally Occurring Carlavirus in Alfalfa
}

\author{
Venkateswarlu Veerisetty and Myron K. Brakke
}

Department of Plant Pathology, University of Nebraska, Lincoln, NB 68583.

Cooperative Investigations, Agricultural Research Service, U.S. Department of Agriculture, and Plant Pathology Department, Nebraska Agricultural Experiment Station, Lincoln, NB 68583. Published with the approval of the Director as Journal Series Paper No. 5181 of the Nebraska Agricultural Experiment Station. Results are from a thesis to be submitted by the senior author for the Ph.D. degree. Present address of senior author: Department of Plant Pathology, University of Missouri, Columbia, MO 65201.

Mention of a trademark name, proprietary product, or specific equipment does not constitute a guarantee or warranty by the U.S. Department of Agriculture and does not imply its approval to the exclusion of other products that also may be suitable. Triton X-100 is a tradename for an alkyl aryl polyethoxy ethanol marketed by Rohm and Haas, Philadelphia, PA 19105. Tween 80 is polyoxyethylene (20) sorbitan monooleate.

We thank M. A. Khan and D. J. Hagedorn for their gifts of red clover vein mosaic virus and its antiserum and pea streak virus, respectively. We are greatly indebted to E. M. Ball for her help in preparing antiserum, to W. R. Kehr for permission to survey his alfalfa clones, and to G. Manglitz for aphids.

Accepted for publication 23 March 1977.

\section{ABSTRACT}

VEERISETTY, V., and M. K. BRAKKE. 1977. Alfalfa latent virus, a naturally occurring carlavirus in alfalfa. Phytopathology 67 : 1202-1206.

Alfalfa latent virus (ALV), a new member of the carlavirus group, was isolated from alfalfa (Medicago sativa) clones from the University of Nebraska experimental plots and from the farmers' fields. The pea aphid, Acyrthosiphon pisum, transmitted this virus to M. sativa, Pisum sativum, and Vicia faba, but not to Trifolium pratense. It was also sap transmissible to $V$. faba, $V$. villosa, and $P$. sativum, but was not seed-borne in $P$. sativum. In $V$. faba sap ALV was infectious at 65 but not at $70 \mathrm{C}$ in $10 \mathrm{~min}$, or after 4 days but not after 6 days at $25 \mathrm{C}$ and after dilution to $10^{-3}$ but not $10^{-4}$. Light microscopy indicated absence of any inclusion bodies in the epidermal strips of $V$. faba and $P$. sativum. With tobacco mosaic virus and a diffraction grating replica as standards, modal lengths of 653 and $635 \mathrm{~nm}$, respectively, were determined for ALV. Serological and host range studies indicate that ALV is unrelated to pea streak virus, red clover vein mosaic virus, and cowpea mild mottle virus, other naturally occurring legume carlaviruses.
Alfalfa (Medicago sativa L.) is grown widely as a fodder crop and most fields are infected with alfalfa mosaic virus (AMV). The possibility of other viruses occurring on alfalfa was investigated and we discovered a flexuous rod and a tobacco mosaic viruslike particle in apparently diseased alfalfa clones collected from the University of Nebraska breeding plots and from farmers' fields. In this report, we describe the isolation, host range, symptomatology, transmission, physical and serological properties of flexuous virus, and call it alfalfa latent virus (ALV).

\section{MATERIALS AND METHODS}

Isolation and sap- and seed-transmission of alfalfa latent virus.-The sap from one of the six alfalfa plants, previously found to contain flexuous viruslike particles, was extracted in water and inoculated onto broad bean (Vicia faba L.), soybean (Glycine max L. Merr. 'Amsoy'), Phaseolus vulgaris L. 'Pinto', and Nicotiana tabacum L. plants. Two wk later flexuous particles (ALV) were detected only in the leaf-dip preparations from broad bean plants. The flexuous rods then were separated from possible AMV contaminants by sucrose density gradient centrifugation. Alfalfa latent virus isolated by the above

Copyright (c) 1977 The American Phytopathological Society, 3340 Pilot Knob Road, St. Paul, MN 55121. All rights reserved. method was maintained in broad bean and pea (Pisum sativum L. 'Lincoln') in a growth chamber at $20 \mathrm{C}$. Water extract of the infected broad bean leaves was used for studies on the host range, dilution end point, thermal inactivation point, and stability at room temperature. Celite was used in these studies to act as an abrasive and all infectivity assays were performed on broad bean. In the host range studies the inoculated and noninoculated leaves pooled from several plants of each test species were back-inoculated to broad bean for the detection of ALV. Seeds collected from infected pea cultivar Lincoln were tested for seed transmission by raising plants from these in a growth chamber at $20 \mathrm{C}$.

Aphid transmission.-Cultures of pea aphids, Acyrthosiphon pisum (Harris), were maintained on alfalfa plants in a greenhouse or on alfalfa cuttings in growth chambers. Infected pea and broad bean were used as virus sources whereas alfalfa, red clover, pea, and broad bean served as test plants. Aphids were fasted for $30 \mathrm{~min}$ and then allowed to probe for $5-10 \mathrm{~min}$ on the virus source plant. Five or more aphids then were transferred to each test plant. Similar numbers of nonviruliferous aphids were used in control tests. One day after the inoculation feeding, the aphids were killed with an insecticide and the plants maintained in the greenhouse for observation.

Partial purification of ALV, PSV, and RCVMV.-Pea streak virus (PSV) and red clover vein mosaic virus 
(RCVMV, ATCC/PV 110) were gifts from D. J. Hagedorn and M. A. Khan, respectively, University of Wisconsin, Madison and were also propagated in Lincoln pea. Frozen infected pea (cultivar Lincoln) tissue was homogenized in a Waring Blendor with two parts $(w / v)$ of $0.165 \mathrm{M}$ disodium phosphate, $0.018 \mathrm{M}$ trisodium citrate buffer, $\mathrm{pH} 9.0$, containing $0.1 \%$ sodium diethyldithiocarbamate (DIECA) and $0.5 \% \beta$-mercaptoethanol (ME). The extract was strained through cheesecloth, centrifuged for $10 \mathrm{~min}$ at $10,000 \mathrm{rpm}$, clarified with calcium phosphate (formed in situ by slow, simultaneous addition of one-twentieth volume $0.2 \mathrm{M} \mathrm{Na}_{2} \mathrm{HPO}_{4}$ and onehundredth volume $1 \mathrm{M} \mathrm{CaCl}_{2}$ with constant stirring for 15-20 $\mathrm{min}$ ) (4) and recentrifuged. From the supernatant fraction, the virus was precipitated by adding $6 \%(\mathrm{w} / \mathrm{v})$ solid polyethylene glycol 6000 (PEG) followed by stirring until the PEG dissolved. The precipitated virus was collected by low-speed centrifugation and resuspended in buffer (one-tenth the molarity of the extraction buffer), one-tenth the original volume of the sap, containing $1 \%$ Triton X-100. After low-speed centrifugation, the supernatant fraction was layered on a pad of $10 \mathrm{ml}$ of $20 \%$ sucrose containing $1 \%$ Triton and centrifuged for $3 \mathrm{hr}$ at $28,000 \mathrm{rpm}$ in the Beckman No. 30 rotor. Pellets were resuspended in buffer containing $1 \%$ Triton, centrifuged for $10 \mathrm{~min}$ at $10,000 \mathrm{rpm}$, and the supernatant liquid was immediately layered on a pad of 5 or $10 \mathrm{ml}$ of $30 \%$ sucrose containing $1 \%$ Triton $\mathrm{X}-100$ and centrifuged at 36,000 rpm for $90 \mathrm{~min}$ or at $28,000 \mathrm{rpm}$ for $3 \mathrm{hr}$, respectively, in a Beckman $\mathrm{Ti} 50$ or No. 30 rotor. The pellets were resuspended in buffer, centrifuged at low speed and the supernatant liquid was designated "partially purified" virus. All low-speed centrifugations were at $10,000 \mathrm{rpm}$ for $10 \mathrm{~min}$ in the SS 34 rotor of the Sorvall RC-2 refrigerated centrifuge. The resuspension buffer was onetenth the molarity of the extraction buffer. Details of the purification procedure, estimation of virus concentration, and the properties of the purified ALV will be presented elsewhere (in preparation).
The above described purification procedure was followed for ALV and PSV. For RCVMV, however, $0.1 \%$ sodium sulfite was substituted for DIECA and ME in extraction buffer, and the calcium phosphate clarification was omitted.

Serology.-Concentrated healthy pea sap was used as a control in serological studies. Frozen healthy pea tissue was homogenized $(2: 1 ; \mathrm{w} / \mathrm{v})$ in a buffer $(0.165 \mathrm{M}$ disodium phosphate, $0.018 \mathrm{M}$ trisodium citrate, $\mathrm{pH} 9.0$ ), strained through cheesecloth, and centrifuged $(10,000$ $\mathrm{rpm}, 10 \mathrm{~min}$ ). The supernatant fraction, after addition of two volumes of $97 \%$ ethanol with $0.15 \mathrm{M}$ sodium acetate, $\mathrm{pH} 5.0$, was stored for a day at $-20 \mathrm{C}$. The resulting precipitate was centrifuged and dried with nitrogen. It then was resuspended in $0.0165 \mathrm{M}$ disodium phosphate, $0.0018 \mathrm{M}$ trisodium citrate buffer, $\mathrm{pH} 9.0(1 \mathrm{ml} / 10 \mathrm{ml}$ of original sap precipitated), incubated for a few hours at room temperature, and centrifuged at $10,000 \mathrm{rpm}$ for 10 min. The resulting supernatant liquid was used for serological studies.

Each of two rabbits were immunized with $4 \mathrm{mg}$ of partially purified ALV in $0.5 \mathrm{ml}$ of $0.0165 \mathrm{M} \mathrm{Na}_{2} \mathrm{HPO}_{4}$, $0.0018 \mathrm{M} \mathrm{Na}_{3}$ citrate buffer, pH 9.0, emulsified with 0.5 $\mathrm{ml}$ Freund's complete adjuvant for the first intramuscular injection. For the second injection, 5 days later, the same amount of virus was emulsified in Freund's incomplete adjuvant. If necessary, a drop or two of $0.1 \mathrm{M} \mathrm{KH}_{2} \mathrm{PO}_{4}$ was added to facilitate emulsification. Two days later, 2 $\mathrm{mg}$ of virus in saline solution was injected intravenously and the rabbits were bled via cardiac puncture 3,4 , and 5 wk later. Antisera titers were determined by the standard microprecipitin tests (1). Serological relationships were tested by the Ouchterlony gel double diffusion tests (1) in $0.5 \%$ Ionagar gels prepared in (i) 1,2 , and $3 \%$ Tween- 80 in distilled water; (ii) $0.02 \mathrm{M}$ tris $\mathrm{HCl}, \mathrm{pH} 9.0$ with $0.1 \mathrm{M}$ $\mathrm{NaCl}, 0.001 \mathrm{M}$ EDTA, $1 \%$ SDS, and $100 \mu \mathrm{g}$ bentonite $/ \mathrm{ml}$; (iii) $0.01 \mathrm{M}$ neutral potassium phosphate; and (iv) in 0.03 to $0.05 \%$ sodium dodecyl sulfate (SDS), $0.025 \%$ sodium azide, $0.0165 \mathrm{M} \mathrm{Na}_{2} \mathrm{HPO}_{4}, 0.0018 \mathrm{M} \mathrm{Na}$

TABLE 1. Transmission of alfalfa latent virus by pea aphids

\begin{tabular}{|c|c|c|c|c|c|}
\hline \multirow[b]{2}{*}{ Aphid source } & \multirow[b]{2}{*}{ Virus source } & \multicolumn{4}{|c|}{ Test plants $^{\mathrm{a}}$} \\
\hline & & Broad bean & Pea & Alfalfa & Red clover \\
\hline $\begin{array}{l}\text { Alfalfa cuttings } \\
\text { in growth chamber }\end{array}$ & $\begin{array}{c}\text { Broad bean } \\
\text { Pea } \\
\text { None }\end{array}$ & $\begin{array}{l}6 / 6 \\
4 / 4 \\
0 / 8\end{array}$ & $\begin{array}{l}\ldots \\
4 / 4 \\
0 / 4\end{array}$ & $\begin{array}{l}0 / 6 \\
1 / 8 \\
0 / 8\end{array}$ & $\begin{array}{l}\dddot{0} \\
0 / 8 \\
0 / 4\end{array}$ \\
\hline $\begin{array}{l}\text { Alfalfa plants } \\
\text { in greenhouse }\end{array}$ & $\begin{array}{l}\text { Pea } \\
\text { Pea } \\
\text { None } \\
\text { None }\end{array}$ & $\begin{array}{l}\cdots \\
\cdots \\
\cdots \\
\cdots\end{array}$ & $\begin{array}{c}4 / 4 \\
\cdots \\
\cdots \\
\cdots\end{array}$ & $\begin{array}{l}1 / 10 \\
5 / 10^{b} \\
1 / 10^{c} \\
1 / 10\end{array}$ & $\begin{array}{l}\cdots \\
\cdots \\
\cdots \\
\cdots\end{array}$ \\
\hline None $^{d}$ & $\begin{array}{l}\text { None } \\
\text { None }\end{array}$ & $\begin{array}{l}\cdots \\
\cdots\end{array}$ & $\begin{array}{l}\ldots \\
\ldots\end{array}$ & $\begin{array}{l}0 / 10^{\mathrm{e}} \\
0 / 10^{\mathrm{e}}\end{array}$ & $\begin{array}{l}\ldots \\
\ldots\end{array}$ \\
\hline
\end{tabular}

\footnotetext{
"Numerator: no. of plants infected. Denominator: no. of plants inoculated.

${ }^{\mathrm{b}}$ The plants were inoculated twice by viruliferous aphids on two different days.

'One of the alfalfa source plants on which aphids were colonized was contaminated with ALV, resulting in virus transmission to the control test plants.

"Alfalfa plants not exposed to aphids constituted a control.

'The lower efficiency of transmission to alfalfa test plants could be due to the use of Dawson alfalfa, which is resistant to pea aphid feeding.
} 
citrate buffer, $\mathrm{pH} 9.0$. A drop of concentrated healthy pea sap was placed in the center well and allowed to completely diffuse. A drop of antiserum was then added to the center well. Simultaneously antigens were placed in the peripheral wells and plates were read one day later.

In our tests RCVMV, its antiserum (supplied by M. A. Khan, University of Wisconsin, Madison), and PSV, also were used. Antigen concentrations of $1,0.7$, and 0.5 $\mathrm{mg} / \mathrm{ml}, 1$ and $0.5 \mathrm{mg} / \mathrm{ml}$, and $1,0.5$, and $0.4 \mathrm{mg} / \mathrm{ml}$ were used for ALV, RCVMV, and PSV, respectively.

Electron microscopy.-Leaf-dips were made in distilled water on carbon-backed Formvar-coated grids and stained with $1.5 \%$ potassium phosphotungstate, $0.25 \%$ ammonium vanadatomolybdate, $\mathrm{pH} 6.5$. Particles were measured directly on negatives with an eyepiece micrometer and low-power microscope. Tobacco mosaic virus (TMV) and a diffraction grating replica $(22,835$ lines $/ \mathrm{cm})$ were used as calibration standards.

Leaf-dip electron microscopy also was used to ascertain the presence of ALV in all test plants. Usually a single grid was prepared using two to three leaves (inoculated and noninoculated upper leaves) of each test plant.

Inclusion bodies. - Epidermal strips from young stems, petioles, and leaves of infected broad bean and pea stained with $1 \%$ methylene blue in Christie's solution (6) either were examined directly with a light microscope or after rinsing with distilled water.

\section{RESULTS}

Isolation of alfalfa latent virus from alfalfa.-Twenty one alfalfa clones of various ages were examined by leafdip electron microscopy and flexuous viruslike particles were observed in six plants only. Upon sap inoculation, from extract of one of these plants, the virus was transmitted to broad bean only. Flexuous virus then was separated from possible AMV contamination by density gradient centrifugation. A neutral $0.01 \mathrm{M}$ potassium phosphate extract of infected broad bean after centrifugation $(10,000 \mathrm{rpm}, 10 \mathrm{~min})$ was made $1 \%$ in Triton X-100 and layered on the top of preformed sucrose

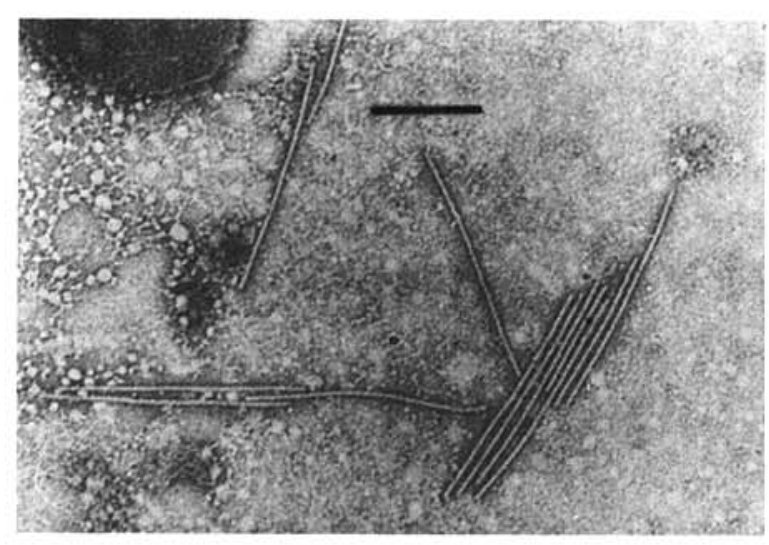

Fig. 1. Electron micrograph of alfalfa latent virus particles in crude sap. Bar represents $275 \mathrm{~nm}$. density gradients (linear, $100-400 \mathrm{mg} / \mathrm{ml}$ in $0.01 \mathrm{M}$ potassium phosphate, $\mathrm{pH} 7.0$ ). After centrifugation at $25,000 \mathrm{rpm}$ for $1 \mathrm{hr}$ and $45 \mathrm{~min}$ (Spinco SW 27 rotor), a light-scattering zone was observed at a depth lower than that expected for AMV. This zone was removed with a syringe, diluted ten-fold in $0.01 \mathrm{M}$ phosphate, $\mathrm{pH} 7.0$, and inoculated onto broad bean. Simultaneously, an aliquot of the same sample was examined by electron microscopy, which indicated the presence of many flexuous particles. Two tests were conducted to eliminate the possibility of AMV contamination in the broad bean plants infected with ALV obtained from the density gradient column. The sap from the broad bean plant was inoculated onto soybean and also tested serologically against AMV antiserum. Soybean was employed because of its susceptibility to AMV but not to ALV. In preliminary inoculations, when the sap from alfalfa plants containing flexuous virus and AMV was inoculated onto soybean, only the AMV was transmitted as indicated by the presence of mosaic symptoms, positive serological reaction with AMV antiserum, and the absence of flexuous rods. Therefore, soybeans inoculated with sap from broad bean, previously inoculated with the zonal sample would have shown disease symptoms if AMV was still present after density gradient centrifugation. These soybeans neither showed disease symptoms nor had virus particles. Ouchterlony gel immuno-diffusion test with sap from broad bean inoculated with the sample from the zone, did not react with AMV antiserum. In this test, the antiserum reacted

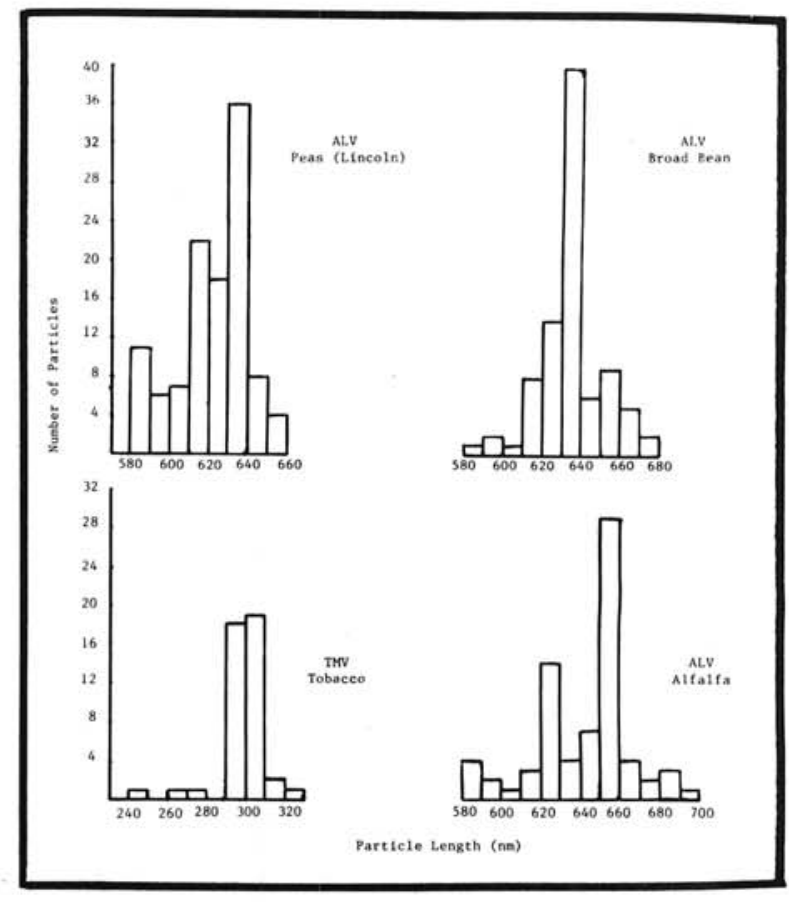

Fig. 2. Particle-length distribution histograms of alfalfa latent virus in different infected plants. Tobacco mosaic virus was used as an internal standard for particles from alfalfa. Diffraction replica grating was used as a standard for particles from broad bean and pea. 
with a strain of AMV maintained on broad bean. This indicated that the flexuous virus was free of $A M V$ in broad bean plants infected by the virus sample from the gradient zone.

Transmission, host range, and symptomatology.-The pea aphids efficiently transmitted the virus to the broad bean and pea plants, regardless of the virus source. When pea served as the source plant, the virus was consistently transmitted to alfalfa (Table 1), but not to red clover. Alfalfa and pea showed no symptoms but young leaves of broad bean had slight reddish-brown to brown necrosis. Alfalfa latent virus was mechanically transmissible to $V$. faba L. (broad bean), V. villosa Roth. (hairy vetch), and to $P$. sativum 'Tall Telephone', 'Alaska', 'Perfected Wales', 'Lincoln', and 'Little Marvel'. It was systemic but symptomless in hairy vetch, Tall Telephone, Perfected Wales, and Alaska peas both at 20 and $26 \mathrm{C}$. Lincoln and Little Marvel peas were symptomless at $26 \mathrm{C}$ but developed faint chlorosis at $20 \mathrm{C}$, which disappeared as the plants grew further. In a growth room at $13 \mathrm{C}$, Lincoln peas showed striking vein clearing, chlorosis of young leaves, and necrosis of old leaves more than 2 mo after inoculation. The upper leaves of the susceptible plants had virus detectable by electron microscopy $2 \mathrm{wk}$ after inoculation. Broad bean reacted with reddish dark-brown necrotic local lesions on inoculated leaves about ten days after inoculation. Brownish to reddish-dark-brown necrosis developed on top leaves, followed by wilting and abscission of the leaves with occasional reddish-darkbrown necrosis on stems.

The following species showed no symptoms and had no virus detectable by electron microscopy or by back inoculation to broad bean: Chenopodium amaranticolor Coste \& Reyn.; C. quinoa Willd.; C. hybridum L.; Gomphrena globosa L.; Nicotiana tabacum L. 'Turkish'; Datura stramonium L.; Phaseolus vulgaris L. 'Pinto', 'Red Kidney', 'Black Turtle Soup', and 'Great Northern'; Trifolium pratense L. (red clover); T. repens L. (white clover); T. hybridum L. (alsike clover); Vigna unguiculata (L.) Walp.; Medicago sativa L. 'Dawson', 'Kanza', and 'Grimm'; Glycine max (L.) Merr., 'Amsoy'; Capsicum frutescens L.; and Cucumis sativus L. 'Chicago Pickling'.

None of 41 pea plants grown from the seeds collected from infected Lincoln peas had virus particles as ascertained with electron microscopy.

Field survey.-Five commercial alfalfa fields around Lincoln, Nebraska, were surveyed for this virus. Apparently diseased alfalfa plants from different fields (eight plants from each field) were tested for virus infection by preparing two grids from each plant. The grids were examined in the electron microscope until the flexuous rods were found in at least two plants from a field. Flexuous rods were readily found in plants from four out of five fields with particle measurement corresponding favorably with that of our original virus culture.

Inclusion bodies. - No inclusion bodies were found by light microscopy in epidermal strips of leaves, stems, and petioles of infected broad bean and pea.

Stability and particle morphology.-The virus in crude sap had a thermal inactivation point of 65 to $70 \mathrm{C}$ at 10 min and a dilution end point of $10^{-3}$ to $10^{-4}$. The crude sap from broad bean was infectious for 4 but not 6 days at 25 C.

Particles of ALV were straight to slightly flexuous rods in the leaf-dips prepared from virus infected broad bean, pea, and alfalfa (Fig. 1). Modal lengths of $635 \mathrm{~nm}$ and 653 $\mathrm{nm}$, respectively, were obtained with diffraction grating replica $(22,835$ lines $/ \mathrm{cm})$ and TMV at $300 \mathrm{~nm}$ as standards. Careful measurements of TMV leading to a length of $300 \mathrm{~nm}$ were done with shadowed preparations $(9,15)$. Since lengths slightly shorter than $300 \mathrm{~nm}$ have been reported for TMV after negative staining (11), the discrepancy in our measurements may reflect merely the uncertainty in the length of TMV. The length distribution of ALV in different hosts is shown in Fig. 2.
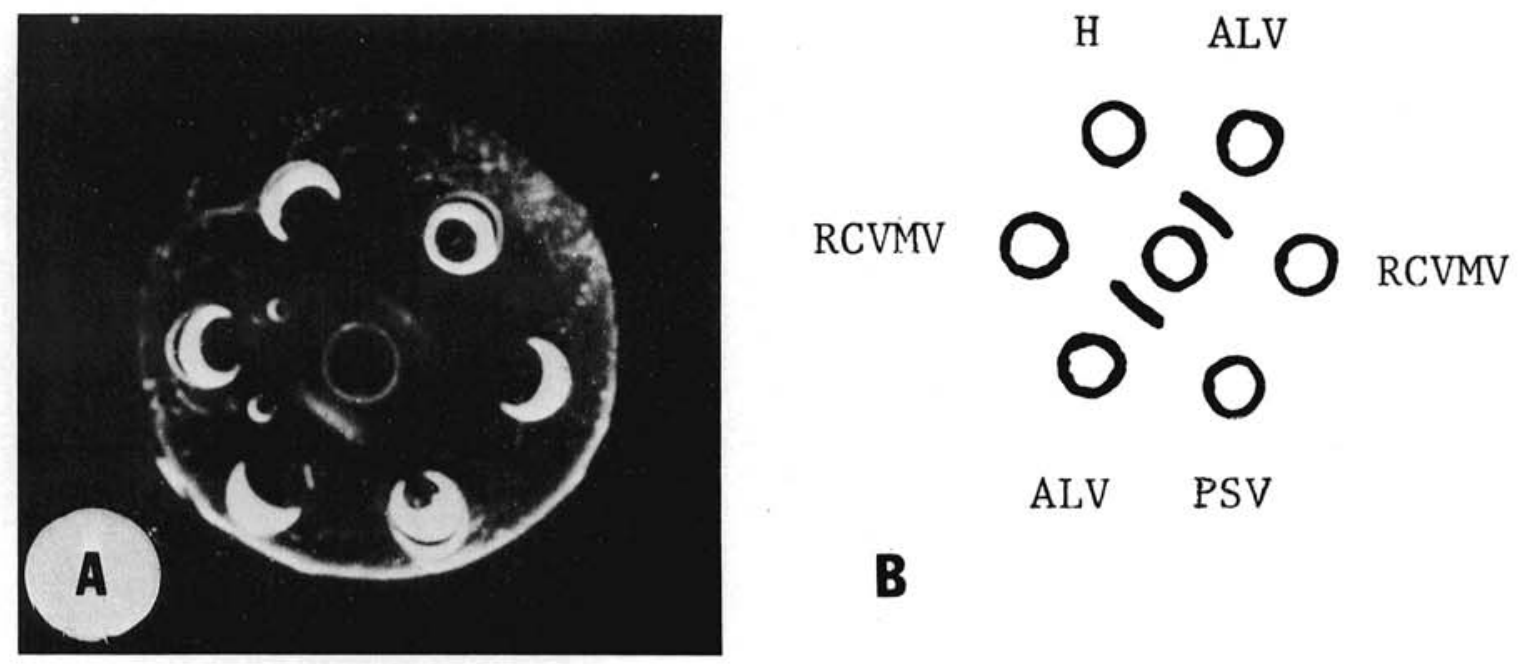

Fig. 3-(A, B). Serological analysis of alfalfa latent virus and two other members of carlavirus group. A) Ouchterlony agar-gel double diffusion test and B) its hand-drawn replica. Center well contains adsorbed alfalfa latent virus antiserum. Outer wells contain different antigens: $\mathrm{H}=$ concentrated healthy pea sap; $\mathrm{ALV}=$ alfalfa latent virus $0.7 \mathrm{mg} / \mathrm{ml} ; \mathrm{RCVMV}=$ red clover vein mosaic virus 1 $\mathrm{mg} / \mathrm{ml}$; and PSV = pea streak virus $0.4 \mathrm{mg} . \mathrm{ml}$. Positive reaction line seen only against homologous antigen. 
Serology.-Antiserum prepared against ALV reacted at a dilution of 1:512 in microprecipitin tests with ALV at $1 \mathrm{mg} / \mathrm{ml}$. Immuno-diffusion tests using lonagar only in $0.05 \%$ or $0.03 \%$ SDS (electrophoretic grade) in $0.0165 \mathrm{M}$ $\mathrm{Na}_{2} \mathrm{HPO}_{4}, 0.0018 \mathrm{M} \mathrm{Na}_{3}$ citrate, $\mathrm{pH} 9.0$, buffer, gave a single consistent and reproducible reaction line at $0.5,0.7$, or $1 \mathrm{mg} / \mathrm{ml}$ ALV concentration. Undiluted ALV antiserum did not react with partially purified RCVMV $(0.5$ and $1 \mathrm{mg} / \mathrm{ml})$, PSV $(0.4,0.5$, and $1 \mathrm{mg} / \mathrm{ml})$, or concentrated healthy pea sap (Fig. 3). In a similar test, RCVMV antiserum gave a single reaction line with RCVMV and PSV but not with ALV. This indicates that ALV is serologically unrelated to RCVMV and PSV.

\section{DISCUSSION}

Cowpea mild mottle virus (CMMV), RCVMV, and PSV are the only previously reported carlaviruses (10) occurring naturally on legume crops. We report that ALV is a new member of this group occurring in alfalfa. Alfalfa latent virus is a flexuous rod-shaped virus like RCVMV, CMMV, and PSV but differs from these in host range, serology, and molecular weight of protein subunit estimated by SDS gel electrophoresis (14). It does not infect C. amaranticolor, C. quinoa, or G. globosa which are the known local lesion hosts for CMMV, RCVMV, and PSV $(2,5,13)$. Alfalfa latent virus is mechanically transmitted to broad bean and pea, but CMMV does not infect either of them. Alfalfa latent virus is easily transmitted by pea aphids, but CMMV is not aphid transmissible (5). On Lincoln peas, PSV produces chlorosis and necrosis on the leaves and extensive stem necrosis, resulting in death of plants, whereas RCVMV produces vein clearing, chlorosis, curling, and downward rolling of young leaves leading to terminal rosetting, stunting, and death of plants. These symptoms are strikingly different from the symptoms caused by ALV. Additionally, ALV does not infect $T$.pratense, T. repens, or T. hybridum which are known hosts of RCVMV and PSV $(7,8)$. No serological relationship was detected between ALV and RCVMV or PSV. Alfalfa latent virus produced no inclusion bodies in broad bean or pea, but RCVMV and PSV produce readily detectable inclusion bodies in the infected plants $(3,12)$. The molecular weight of the coat protein subunit of ALV differs strikingly from that of RCVMV and PSV (14), as well as the reported value for CMMV protein (5).

\section{LITERATURE CITED}

I. BALL, E. M. 1974. Serological tests for the identification of plant viruses. Am. Phytopathol. Soc., St. Paul. 31 p.

2. BOS, L. 1973. Pea streak virus. No. 112 in Descriptions of plant viruses. Commonwealth Mycological Institute, Association of Applied Biologists, Kew, Surrey, England. $4 \mathrm{p}$.

3. BOS, L., and M. RUBIO-HUERTOS. 1972. Light and electron microscopy of pea streak virus in crude sap and tissue of pea (Pisum sativum). Neth. J. Plant Pathol. 78:247-257.

4. BRAKKE, M. K. 1962. Stability of purified barley stripe mosaic virus. Virology 17:131-142.

5. BRUNT, A. A., and R. H. KENTEN. 1973. Cowpea mild mottle, a newly recognized virus infecting cowpeas (Vigna unguiculata) in Ghana. Ann. Appl. Biol. 74:67-74.

6. CHRISTIE, R. G. 1967. Rapid staining procedures for differentiating plant virus inclusions in epidermal strips. Virology 31:268-271.

7. HAGEDORN, D. J., and E. W. HANSON. 1951. A comparative study of the virus causing Wisconsin pea stunt and red clover vein mosaic virus. Phytopathology 41:813-819.

8. HAGEDORN, D. J., and J. C. WALKER. 1949. Wisconsin pea streak. Phytopathology 39:837-847.

9. HALL, C. E. 1958. Length of tabacco mosaic virus from electron microscopy. J. Am. Chem. Soc. 80:2556-2557.

10. HARRISON, B. D., J. T. FINCH, A. J. GIBBS, M HOLLINGS, R. J. SHEPHERD, V. VALENTA, and C. WETTER. 1971. Sixteen groups of plant viruses. Virology 45:356-363.

11. MARKHAM, R., J. H. HITCHBORN, G. J. HILLS, and S FREY. 1964. The anatomy of the tobacco mosaic virus. Virology 22:342-359.

12. RUBIO-HUERTOS, M., and L. BOS. 1973. Light and electron microscopy of red clover vein mosaic virus in pea (Pisum sativum). Neth. J. Plant Pathol. 79:94-103.

13. VARMA, A. 1970. Red clover vein mosaic virus. No. 22 in Descriptions of plant viruses. Commonwealth Mycological Institute, Association of Applied Biologists, Kew, Surrey, England. 4 p.

14. VENKATESWARLU, V. 1975. Apparent molecular weights of RNA and protein subunits of carlaviruses. Proc. Am. Phytopathol. Soc. 3:144 (Abstr.).

15. WILLIAMS, R. C., and R. L. STEERE. 195I. Electron microscopic observations on the unit length of the particles of tobacco mosaic virus. J. Am. Chem. Soc. 73:2057-2061. 